\title{
INVENTARISASI DATA LINGKUNGAN FISIK DAERAH RENCANA KAWASAN WISATA JIMBARAN-KEDONGANAN BALI
}

\author{
Oleb: \\ Suprapto Dibyosaputro*)
}

\begin{abstract}
Jimbaran and Kedonganan areas is once among the areas which are planed to be a coastal tourism area in Bali Island. Purposes of the research was to data inventory on physical environment such as climate, geomorphology, geology, soil, bydrology and oceanography. In this research the observation method was carried out by mean of observe, measuremment and denote of the physical environmental aspects both in the filed and laboratory works.

The results of the research indicate that mest of the Jimbaran annd kedonganan areas have highly potention of physical environmental aspects in supporting the tourism sreas. The average temperature is about $27.05 \%$ with the highest temperature is $29^{\circ} \mathrm{C}$ occur in October and the lowest temperature is $26^{\circ}$ occurs in August. Annual rain fall is 1240 millimeters, with the wet moth bertwwn December and april, while rest of the other monthbs are dry monnths.

From the geomorphological point of view the area of study is a bay situated in the west side of the neck of tombelo. In this location the visitors could see the sun set event during evening time. At the southern part of the area is bordered by a beatuifully natural panorama of limestone cliff. The depth the thick of water is about 0.65-1.00 meters. The average amount of ground areas is about 5,913,600 cubic meters. With mosat $p H$ of water more than 7 because of sea water intruxion. Doe to limited ground water potention the area is necessary to be suplied by water from out side areas in order to cover the need of water for hotels.

The Jimbaran and Kedongannan bay has various of wave beight between 0.25-1.60 meters, beach of 75-100 meters in wide, and $5^{\circ}-7^{\circ}$ of beach slopes. Some small promontories and bays lay on the main Jimbaran and Kedonganan bay always dynnamically moves from place to place. As The effect of this movement it to the changing position of rip current periodically. It make danger condition for the swimmers because they should know where the location of rip current is.
\end{abstract}

\section{INTISARI}

Daerab Jimabaran dan Kedonganan adalab merupakan salab satu daerab yang direncanakan untuk kawasan pariwisata pantai Pulau Bali. Tujuan penelitian ini adalab méngadakan inventarisasi data lingkungan fisik daerab tersebut yang meliputi iklim, geomorfologi, tanah, bidrologi, dan oceanografi. Adapun metode penelitian yang 
digunakan adalab metode observasi yakni pengamatan, pengukuran dan pencatatan terbadap aspek-aspek tersebut baik langsung di lapangan maupun dilaboratorium.

Hasil penelitian menunjukan babwa wilayah Jimbaran dan Kedonganan sebagian besar mempunyai potensi lingkungan fisik yang baik sebagai kawasan wisata pantai. Subu rata-rata adalab $27.05^{\circ} \mathrm{C}$ dengan subu tertinggi terjadi pada Bulan Oktober yakni $29^{\circ} \mathrm{C}$ dan subu terendah pada bulan Agustus yakni $26^{\circ} \mathrm{C}$. Hujan rata-rata setabun adalab $1240 \mathrm{~mm}$ dengan bualn-bulan basab antara Desember bingga April, sedang bulan-bulan lainnya adalab bulan kering. Secara geomorfologis' daerab penelitian merupakan teluk dimana dari tempat ini dapat melibat panorama alam yang indab yakni terbenamnya matabari diwaktu sore. Daerab ini juga merupaan bagian leber dari suatu tombolo. Sebelab selatan daerab penelitian berbatasan dengann cliff dari batu gamping yang menambab keindaban panorama alami. Kedalaman air tanah bervariasi antara 4-7,65 meter dengan tebal air tanah antara 0,65-1,00 mmeter. Potensi air tanah sebesar 5.913.600 $\mathrm{mm}^{3}$, dengan pH air di beberapa daerah 7 karena adanya intrusi air laut. Potensi tersebut tidak mencukupi untuk kebutuhan air untuk keperluan botel-hotel di wilayah ini sebingga harus menambah air dari luar kawasan tersebut.

Wilayah teluk Jimbaran-Kedonganan ini mempunyai tinggi gelombang antara 0,25-1,60 meter, frekuensi gelombang antara 10-15 buab gelombang permenit, lebar gisk antara 75-100 meter, dengan kemiringan gisik $5^{\circ}-7^{\circ}$. Di dalam teluk Jimbaran Kedonganan ini terdapat adanya teluk dan tanjung yang kecil yang letaknya selalu berpindah-pindah. Hal ini berbahaya bagi perenang di laut karena arus balik kuat (rip cureent) ke arah laut berpindah-pindah tempat pada periode waktu tertentu.

\section{PENDAHULUAN}

Pembangunan merupakan upaya sadar untuk mengelola dan memanfaatkan sumber daya guna meningkatkan mutu kehidupan rakyat. Sumberdaya bukan merupakan suatu yang tidak terbatas keberadaannya, baik dalam hal kuantitas maupun kualitasnya. Sementara dipihak lain kebutuhan manusia akan sumberdaya alam semakin meningkat dengan meningkatnya jumlah penduduk serta meningkatnya kebutuhan hidup. Hal ini akan mengakibatkan terganggunya daya dukung lingkungan dan menurutnya kualitas lingkungan hidup.

Akibat semakin meningkatnya pembangunan di semua sektor adalah akan menanggung resiko pencemaran lingkungan, karena aktivitas pembangunan dapat mengganggu fungsi ekosistem dan sosial yang ada. Oleh karena itu pembangunan yang bijaksana harus dilandasi dengan suatu prinsip wawasan lingkungan sebagai sarana untuk mencapai kesinambungan dan menjadi jaminan bagi generasi sekarang dan yang akan datang.

Salah satu pembangunan yang dilaksanakan oleh pemerintah adalah pembangunan sektor kepariwisataan. Dalam masa Pelita $V$ ini pemerintah telah mencanangkan suatu kebijaksanaan untuk meningkatkan pengembangan pariwisata dengan melaksanakan pembangunan kawasan pariwisata. Pada dasarnya kawasan pariwisata adalah suatu lahan dengan batas luas tertentu, yang sebagian atau seluruhnya diperuntukkan bagi pengembangan dan atau telah memiliki kelengkapan prasarana dan sarana pariwisata serta sistim pengelolaannya. 
Salah satu kawasan pariwisata yang akan dikembangkan adalah kawasan Jimbaran-Kedonganan yang terletak di sebelah selatan Bandara Internasional Nngurah Rai, Pulau Bali (Peta 1).

Ditinjau dari jenis kawasan pariwisata, pada dasarnya kawasan pariwsata dapat dibagi kedalam dua bentuk yaitu:

1. Kawasan pariwisata murni, yaitu kawasan yang seluruhnya diperuntukkan bagi pengembangan pariwisata.

2. Kawasan pariwisata terbuka, yaitu kawasan yang bobotnya diperuntukkan bagi pengembangan pariwisata. Di dalam kawasan ini kegiatan lain dari masyarakat umum seperti pertanian, perkebunan, sebagai tempat permukiman dan lain-lain masih terbuka, hanya diatur dan ditata agar dapat mendukung pengembangan pariwisata.

Adapun rencana bentuk dari daerah penelitian ini adalah merupakan kawasan wisata pantai yang bersifat terbuka. Sifat obyek pariwisata pada dasarnya dikelompokkan kedalam dua sifat yaitu pariwisata alami dan pariwisata non alami, yang masingmasing mempunyai faktor-faktor kepariwisataan seperti disajikan pada Bagan 1.

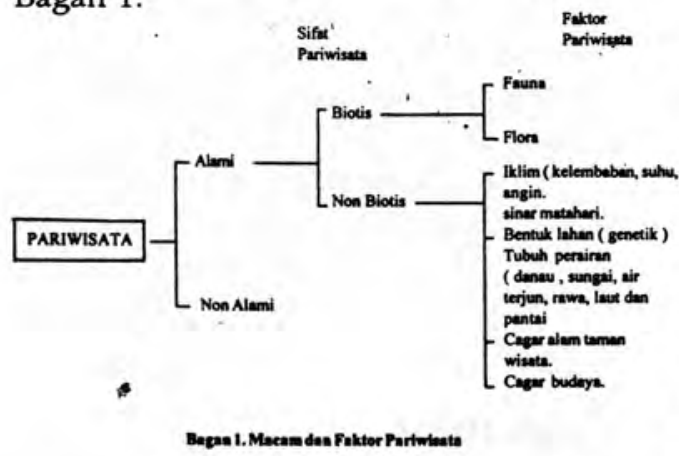

Dari Bagan 1 tersebut dapatlah disusun dalam suatu struktur data yang diperlukan didalam perencanaan pengembangan suatu lokasi untuk kegiatan kegiatan pariwisata seperti disajikan pada Bagan 2.

Dengan memperhatikan bentuk pariwisata dan struktur sumberdaya alam yang perlu dipertimbngkan dalam pengembangan kawasan pariwisata, maka penulis tertarik untuk meneliti dan menginventarisasi struktur sumberdaya alam yang terdapat di kawasan Jimbaran-Kedonganan, Kabupaten Badung, Bali.

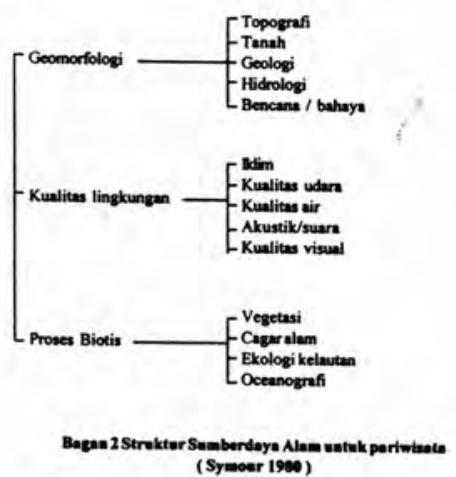

Bagan 2. Struktur Sumberdaya Alam untuk pariwisata *Syamour 1980)

\section{TUJUAN PENELTIAN}

Penelitian ini bertujuan untuk inventarisasi data lingkungan fisik daerah rencana kawasan pariwisata Jimbaran-Kedonganan, Kabupaten Badung, Pulau Bali.

Untuk maksud tersebut sasaran yang dicapai dalam penelitian ini meliputi:

a. Iklim

b. Geomorfologi

c. Geologi

d. Tanah

e. Hidrologi

f. Oceanografi 


\section{CARA PENELITIAN}

Cara penelitian ini dilakukan dalam beberapa tahap, yaitu tahap persiapan, survey lapangan dan tahap penyelesaian.

Dalam tahap persiapan dilakukan pembuatan peta bentuk lahan tentatif yang didasarkan pada hasil interpretasi peta topografi dan peta geologi. Selain itu dilakukan pula pengumpulan data sekunder berupa laporan-laporan yang berkaitan dengan topik penelitian seperti data iklim, data pasang surut, penggunaan lahan, dan tanah.

Survei lapangan dimaksudkan untuk mengecek dan melengkapi hasil pemetaan bentuk lahan, pengukuran kedalaman air tanah dan EC dari sumur penduduk, pengambilan sampel air tanah maupun air permmukaan, deskripsi sifat, fisik tanah, pengukuran gelombang, lebar mintakat pasang surut air laut, morfometri pantai, serta pengecekan terhadap penggunaan lahan.

Beberapa sampel tanah dan air dianalisa di laboratorium untuk mengetahui sifat fisik dan kimia tanah serta kualitas air baik air permukaan maupun air tanah.

Semua data lingkungan fisik yang telah dikumpulkan baik hasil pengukuran langsung di lapangan maupun hasil analisa laboratorium disusun dalam suatu bentuk inventarisasi data lingkungan fisik daerah rencana kawasan pariwisata Jimbaran - Kedonganan, Pulau Bali.

\section{HASIL DAN PEMBAHASAN}

\section{A. Hasil Penelitian}

Inventarisasi data lingkungann fisik dimaksudkan untuk menyajikan data komponen lingkungan fisik daerah Jimmbaran - Kedonganan, Pulau Bali yang merupakan data struktur sumberdaya alam dan merupakan faktor yang harus dipertimbangkan dalam pengembangan lokasi yang akan dijadikan kawasan pariwisata. Berikut ini disajikan hasil inventarisasi data lingkungann fisik tersebut.

\section{Iklim}

Data iklim yang dimaksud meliputi: suhu, kelembaban, curah hujan, arah dan kecepatan angin, tekanan udara dan penguapan.

\section{Suhu dan kelembaban}

Berdasarkan data hasil pencatatan di Stasiun Klas I Ngurahh Rai dari periode tahun 1988-1991, suhu rata-rata tahunan sebesar $27,05^{\circ}$ C.Suhu bulan tertinggi terjadi pada bulan Mei dan Oktober yaitu sebesar $29^{\circ} \mathrm{C}$ dan suhu terendah sebesar $26^{\circ} \mathrm{C}$ terjadi pada bulan Agustus.

Kelembaban relatif rata-rata sebesar $80,15 \%$, denan kelembaban relatif tertinggi sebesar $84 \%$ terjadi pada bulan Januari, sedang kelembaban terendah sebesar $74 \%$ terjadi pada bulan Juni.

Hasil pencatatan menunjukkan terjadinya kenaikan suhu dari tahun ke tahun, dan ada kecenderungan kelembaban relatif menurun dari tahun ke tahun.

\section{Curah Hujan}

Besarnya curah hujan rata-rata tahunan yang tercatat di stasiun Tuba, Bali adalah 
$1240 \mathrm{~mm}$, dengan bulan-bulan basah adalah Desember sampai dengan bulan April. Curah hujan terbesar terjadi pada bulan Januari yaitu besar $407 \mathrm{~mm}$, sedang bulan-bulan lainnya curah hujan sangat bervariasi tidak merata. Apabila dibandingkan dengan pengamatan di stasiun Ngurah Rai, curah hujan rata-rata tahunan sebesar $1365 \mathrm{~mm}$. Curah hujan tertinggi sebesar $384 \mathrm{~mm}$ terjadi pada bulan Januari, sedang curah hujan terendah sebesar $33 \mathrm{~mm}$ terjadi pada bulan Agustus.

Menurut penggolongan iklim dari Schmidt dan Ferguson yang mempertimbangkan bulan kering dan bulan basah, maka daerah penelitian termasuk tipe iklim $\mathrm{C}$ denan nilai $\mathrm{Q}$ sebesar $54 \%$.

\section{Arah dan kecepatan angin}

Kecepatan angin rata-rata bulanan yang tercatat di stasiun klimatologi Tuban, Bali adalah sebesar 14.05 $\mathrm{km} / \mathrm{jam}$, sedangkan apabila dibandingkan dengan kondisi kecepatan angin yang tercatat di stasiun meteorologi Ngurah Rai adalah rata-rata sebesar $9,6 \mathrm{~km} / \mathrm{jam}$.

Arah angin di daerah penelitian ini dapat digolongkan kedalam dua arah dominan yaitu arah Timur-Tenggara dan arah Barat-barat daya.

\section{Tekanan Udara}

Hasil pencatatan tekanan udara di stasiun meteorologi Ngurah Rai dari 1984-1988 menunjukkan bahwa tekanan udara rata-rata tahunan adalah sebesar 1009,98 mbar, dengan tekanan udara maksimem sebesar 1011,09 mbar tercatat pada tahun 1987 dan tekanan terendah sebesar 1009,68 mbar tercatat pada tahun 1984. Tekanan udara maksimum terjadi pada bulan Juni yaitu sebesar 1015,90 mbar, dan tekanan udara minimum sebesar $1003,70 \mathrm{mbar}$ terjadi pada bulan Januari.

\section{Penguapan (Evaporasi)}

Besarnya penguapan ratá-rata adalah $5,4 \mathrm{~mm} / \mathrm{hari}$, dengan penguapan tertinggi adalah sebesar 5,69/ $\mathrm{mm} / \mathrm{hari}$ terjadi pada tahun 1985 dan pe. nguapan terendah sebesar $5,1 \mathrm{~mm} /$ hari terjadi pada tahun 1986. Pada tahun 1988 diperoleh data besarnya penguapan tahunan rat-rata sebesar $5,35 \mathrm{~mm} / \mathrm{hari}$ dengan penguapan mak simum sebesar $10,3 \mathrm{~mm} /$ hari terjadi pa da bulan Januari dan penguapan mini mum sebesar $0.2 \mathrm{~mm} /$ hari terjadi pada bulan September.

\section{Geomorfologi}

Secara geomorfologis daerah penelitian merupakan suatu bentuk tombolo yakni suatu penomena geomorfologis dimana perbukitan Semenanjung Bukit yang semula berupa pulau telah dihubungkan oleh endapan aluvium marin yang memanjang dengan pulau utama Bali di sebelah utara.

Adapun bentuk lahan penyusun daerah penelitian disajikan pada Peta 2 yang terdiri dari:

a. Bentukan asal Marin yang meliputi:

1) hamparan pasang surut (MI)

2) Gisik Aktif (M2)

3) Gisik Tidak Aktif (M3)

4) Rawa bakau (M4)

b. Bentukan asal Fluvial

1) Dataran Aluvial (F1)

c. Bentukan asal Denudasional

1) Lereng Kaki Pebukitan (D)

d. Bentukan asal Solusional-Denudasional

1) Perbukitan Batugamping (K) 


\section{Geologi}

Daerah penelitian tersusun dari tiga jenis batuan yang berturut-turut dari arah utara ke selatan adalah sebagai berikut:

1) Endapan Aluvium berumur Kuarter Atas yang terdiri dari fragmen pasir kasar dan merupakan campuran hancuran batu-batu gamping dan rumah binatang karang, degan ketebalan 6-7 meter.

2) Endapan aluvium Kuarter Atas yang terdiri dari endapan lempung laut, pasir dan fragmen rumah binatang karang dan hancuran rumah kerang.

3) Batugamping, menempati bagian selatan daerah penelitian dan merupakan perbukitan batugamping yang luas.

\section{Tanah}

Berbagai jenis tanah yang terdapat di daerah penelitian adalah regosol, aluvial hidromorf kelabu dan litosol. Regosol menempati dataran aluvial dan gisik yang tersusun dari endapan pasir kasar yang telah mengalami sedikit lapuk di dekat permukaan tanah.

Aluvial hidromorf menempati daerah rawa bakau dan hamparann pasang surut. Tanah berwarna hitam hingga kelabu pucat, tektur sangat halus, dengan $\mathrm{pH}$ antara 4,5 - 5,5. Tingkat drinase dakhil sangat jelek.

Litosol dijumpai pada perbukitan batugamping yang mempunyai solum sangat tipis $(15 \mathrm{~cm})$

\section{Hidrologi}

\section{Air permukaan}

Di daerah ini hanya ada satu alur sungai yang mengalir dari daerah lereng kaki perbukitan menuju daerah hamparan rawa pasang surut, dan membentuk pola antasan (creek).
Karena kondisi tanah yang pada ujumnya betekstur pasir kasar hingga geluh maka apabila terjadi hujan sebagian air hujan meresap kedalam tanah.

Di bagian selatan daerah penelitian yang tersusun dari batugamping dijumpai adanya rembesan (seepage) dengan debit sangat kecil $(0,1$ liter/detik). Penelitian ini dilakukan pada saat musim kemarau, sehingga tidak dapat mengambil contoh air permukaan. Namun dari data yang ada yang terdiri dari air rawa, air kolam dan air sungai dapatlah diinventarisir hasil analisa air tersebut.

Air rawa menunjukkan adanya zat kimia yang tinggi mendekati sifat air laut. Hal ini ditandai dengan adanya kandungan $\mathrm{Na}, \mathrm{Ca}, \mathrm{Mg}, \mathrm{K}$, dan $\mathrm{C} 1$. serta Daya Hantar Listrik (DHL) yang tinggi.

Dari contoh air sungai diperoleh data kualitas air sebagai berikut: air menunjukkan adanya pengaruh air laut, terlihat dari nilai DHL tinggi, kadar $\mathrm{Ca}$, $\mathrm{Na}, \mathrm{Mg}, \mathrm{K}$ dan $\mathrm{C} 1$ yang sangat tinggi.

\section{Air tanah}

Air tanah erat hubungannya dengan kondisi geologi, geomorfolgi suatu daerah. Atas dasar kondisi geomorfologi tersebut agihan air tanah dapat dikelompokkan sebagai berikut:

1) Kawasan Jimbaran-Kedoganan Sebelah utara.

Potensi air tanah dangkal adalah kecil hingga sedang, dan potensi air tanah dalamnya adalah kecil karena terpengaruh oleh air asin dari air laut. Kedalaman air tanah bervariasi antara 4,00 - 7,65 meter dari permukaan tanah, dengan ketebalan air antara 0,65 - 1,00 meter. Dengan ketebalan air tanah 0,66 meter dan luas daerah peneltian sekitar $896 \mathrm{Ha}\left(8,96 \mathrm{Km}^{2}\right)$, maka 
pada musim kemarau mempunyai potensi air tanah sebesar 5.913 .600 $\mathrm{m}^{3}$. atau sebesar $5,91 \mathrm{~m}^{3} / \mathrm{km}^{2}$. Sedangkan debit sumur yang diperbolehkan untuk dipompa guna kepentigann rumah tangga diperkirakan sebesar $\pm 0,5 \mathrm{~m} 3$ /hari. Adapun agihan kedalaman air tanah disajikan pada Peta 3.

Sebagian besar air sumur penduduk yang ada di daerah penelitian mempunyai $\mathrm{pH}>7$. Hal ini disebabkan adannya pengaruh intrusi air laut kedalam air tanah. Adapun agihan dan pola kontur daya hantar listrik daerah penelitian disajikan pada Peta 4. Dari peta tersebut dapatlah dilihat bahwa daerah rencana kawasan pariwisata sejauh 50 meter ke arah darat dari garis pantai telah terkena intrusi air laut, baik pantai Barat maupun pantai timur. Kenyataan ini dibuktikan dengan adanya kadar $\mathrm{C} 1$ tinggi (17,85-19,542 ppm).

2) Kawasan Jimbaran-Kedonganan Sebelah Selatan.

Kawasan ini didominasi oleh batugamping dengan banyak diaklas. Oleh karena itu sebagian besar air hujan yang jatuh akan masuk kedalam tanah melalui diaklas dan menjadi air di bawah tanah. Pada daerah ini air tanahnya termasuk air tanah dalam. Hal ini dapat dilihat adanya sumur bor yang dibuat oleh PZAT untuk memenuhi kebutuhan hotel dan penduduk.

\section{Oceanografi}

Pantai barat Jimbaran-Kedonganan adalah merupakan teluk yang dibatasi sebelah" utara oleh hamparan pasang surut batugamping koral dengan jetty landasan pesawat udara, dan dibagian selatan dibatasi oleh dinding terjal (cliff) batugamping. Semenanjung Bukit. Arus diperairan teluk ini merupakan arus sekunder yang merupakan hasil refraksi arus utama Samudra Hindia. Arus refraksi tersebut berputar dan mengabrasi bagian pantai selatan daerah penelitian yang berbatugamping sehingga membentuk dinding terjal (cliff). Setelah menghempas dinding terjal tersebut arus kemudian dipantulkan (refleksikan ke arah timur laut dan mengabrasi pantai Jimbaran-Kedonganan, sehingga membentuk bentuk teluk yang lebar (peta 5). Adanya "mini crecenntric beach" yang berkembang didalam teluk tersebut menunjukkan adanya dinamika pantai akibat erisi dan deposisi secara terus meneru. Pantai JimbaranKedonganan mempunyai topografi miring dengan lereng gisik antara $5^{\circ}-7^{\circ}$ ke arah laut. Tinggi gelombang bervariasi antara $0,25-1.60$ meters, dengan frekuensi gelombang antara 10 -15 buah gelombang permenit. Air pasang terjadi rata-rata pada jam 11.00 13.00 , sedang air surut terjadi pada jam 06.00 - 07.00 dan pada jam $17.00-19.00$. Adapun lebar gistik (batas antara pasang maksimum dan surut minimum) berkisar antara 75 - 150 meter.

Apabila ditinjau dari sejak di bangunnya dan berfungsinya jetty landasan pesawat udara Ngurah Rai yang telah dibangun 15 tahun yang lalu, tampak adanya pemunduran garis pantai terutama di sebelah selatan jetty pada pantai Jimbaran - Kedonganan. Hal ini tampak jelas adanya kenampakkan hancuran batugamping koral ini dekat pantai yang lebarnya kurang lebih 10 meter dari garis pantai dan hamparan koral (platform) yang menjorok ke laut selebar kurang lebih 40 meter. Hamparan koral ini tampak jelas disaat air laut pada keadaan surut mini- 
mum.

Dengan memperhatikan pola arus laut (Gambar 8) dan hasil survei lapangan, maka dapat di duga bahwa salah satu penyebab berubahnya pola arus laut dan abrasi pantai Jimbaran Selatan adalah akibat pembangunan jetty tersebut.

Berdasarkan hal tersebut di atas, yakni waktu berfungsinya jetty (kurang lebih 20 tahun yang lalu) dan lebar hamparan koral sebesar kurang lebih 50 M, maka dapatlah diperkirakan besamya abrasi adalah $50 \mathrm{M}-20 \mathrm{th}=$ .259 meter/ tahun atau $=19 \mathrm{~cm} /$ bulan. *

Dengan mengetahui kecepatan abrasi dan lebar pantai disaat air laut surut minimum yaitu antara $75-100$ meter perlu adanya usaha konservasi garis pantai.

\subsection{Pembahasan}

Salah satu daerah di Indonesia yang mempunyai potensi pariwisata yang sudah berkembang daan dikenal oleh dunia Internasional adalah pulau Bali. Secara alamiah pulau ini menarik untuk di lihat dan dinikmati keindahan alam dan budayanya. Hal tersebut didasarkan pada peningkataan ini di perkirakan akan semakin berlipat ganda apabila di tunjang dengan fasilitas-fasilitas yang memadai dan pengembangan obyekobyek yang ada sehingga para wisatawan dapat menikmati kekayaan dan keanekaragaman potensi pariwisata di pulau Bali. Oleh karena itu pengembangan potensi pariwisata ini terus di lakukan oleh Pemerintah dengan melakukan Pembanguman kawasankawasaan baru pariwisata harus mempunyai sumber daya alam yang potensial untuk maksud tersebut. Walaupun demikian pembangunan kawasan pariwisata harus memperhatikan faktor-faktor yang mendukng pembangunan kawasan pariwisata dan perlu disertai dengan perencanaan yang matang karena pembangunan suatu kawasan pariwisata akan memelukan dan. atau modal yang cukup besar disamping lahan yang cukup luas.

Jimbaran dan Kedonganan, Kabupaten Badung, merupakan daerah yang akan dibangun sebagai kawasan wisata di Pulau Bali. Ditinjau lokasinya, daerah ini sangat mudah di jangkau dan dekat dengan lapangan terbang internasional Ngurah Rai, dan letak diantara pusat-pusat pariwisata di Pulau Bali bagian Utara dan Semenanjung Bukit. Selain itu daerah ini mempunyai potensi alami yang baik yaitu dengan pasir pantai berwarna putih, om bak yang tidak begitu besar, dan dapat menikmati pemandanganyang indah di saat matahari akan terbenam (sun set).

Apabila di tinjau dari sumber daya alam yang lain yang merupakan komponen lingkungan fisik, maka di beberapa hal komponen Komponen-komponen lingkungan fisik yang kurang mendukung tersebut antara lain sebagai berikut:

\section{a. Tanah}

Apabila ditinjau dari segi tanah untuk tempat bangunan tanah di daerah penelitian kurang kompak. Tanah yang bertekstur pasir ini mempunyai beban titik rendah yaitu sekitar $3,0-5 \mathrm{~kg} / \mathrm{cm} 2$ persegi yang berarti termasuk katagori rendah. Akibatnya apabila dibangun suatu bangunan yang berat tanah akan mengalami pemampatan terlebih dahulu.

b. Kualitas air minum

Kualitas air minum tanah telah banyak berpengaruh oleh air laut yakni dengan ditandai tingginya kandungan garam (C1).

Disamping itu kadar Ca pada beberapa tempat juga tinggi. Dengan demikiaan perlu adanya treatmen terlebih dahulu terhadap air di daerah tersebut untuk dapat digunakan untuk keperluan masak maupun air minum. 
Dengan demikian perlu adanya treatment terlebih dahulu sebelum dipergunakan untuk keperluan air minum dan memasak.

c. Kuantitas air tanah

Cadangan air tanah adalah sedikit serta kualitas yang tidak baik. Hal ini disebabkan tipisnya akifer serta dangkalnya lapisan permeabel di bawah akifer. Oleh karena itu sudah pasti harus mendatangkan air bersih dari luar daerah penelitian yang membawa efek terhadap biaya tinggi untuk keperluan hotel dan sarana pariwisata lainnya. d. Pantai yang dinamis. Adanya pembentukan teluk dan tanjung di dalam teluk utama JimbaranKedunganan menjadikan letak arus balik deras (rip current) berpindah-pindah. Hal ini merupakan kondisi yang berbahaya bagi para wisatawan yang belum paham tentang kondisi pantai dan dinamika arus didepan pantai, sehingga perlu pemantauan letak teluk dan tanjung setiap waktu.

\section{DAFTAR PUSTAKA}

ANONIM, 1990. Pokok-pokok Pikiran Pengemanngan dan Pengelolaann Kawasan Pariwisata, Departeman Pariwisata, Pos, dan Telekomunikasi, Jakarta. ANONIM, 1974. Land Capability Classification for Recreation Ministry of Planning and Development Town and Country Planninng Division, Techical Paper No. 1

McRae, S.G. and Burnham, C.P. 1981. Land Evaluuation. Ocford Press. London Oka AYoeti, 1985. Pengantar Ilmu Pariwisata. Angkasa, Bandung.

Seymour M.G. 1980. Recreation Planning and Design. Mcgraw Hill, Tokyo. Stephen Smit. 1983. Recreation Geograpby. Longman. Londons.

Sarwono Harjowigeno. 1988. Penerapan Survei Tanab Untuk Bidang Bukan Pertanian. Pertemuan Teknik Pembakuan Sistim Klasifikasi dan Metode Survei Tanab. BAKOSURTANAL-PPT., Bogor. 


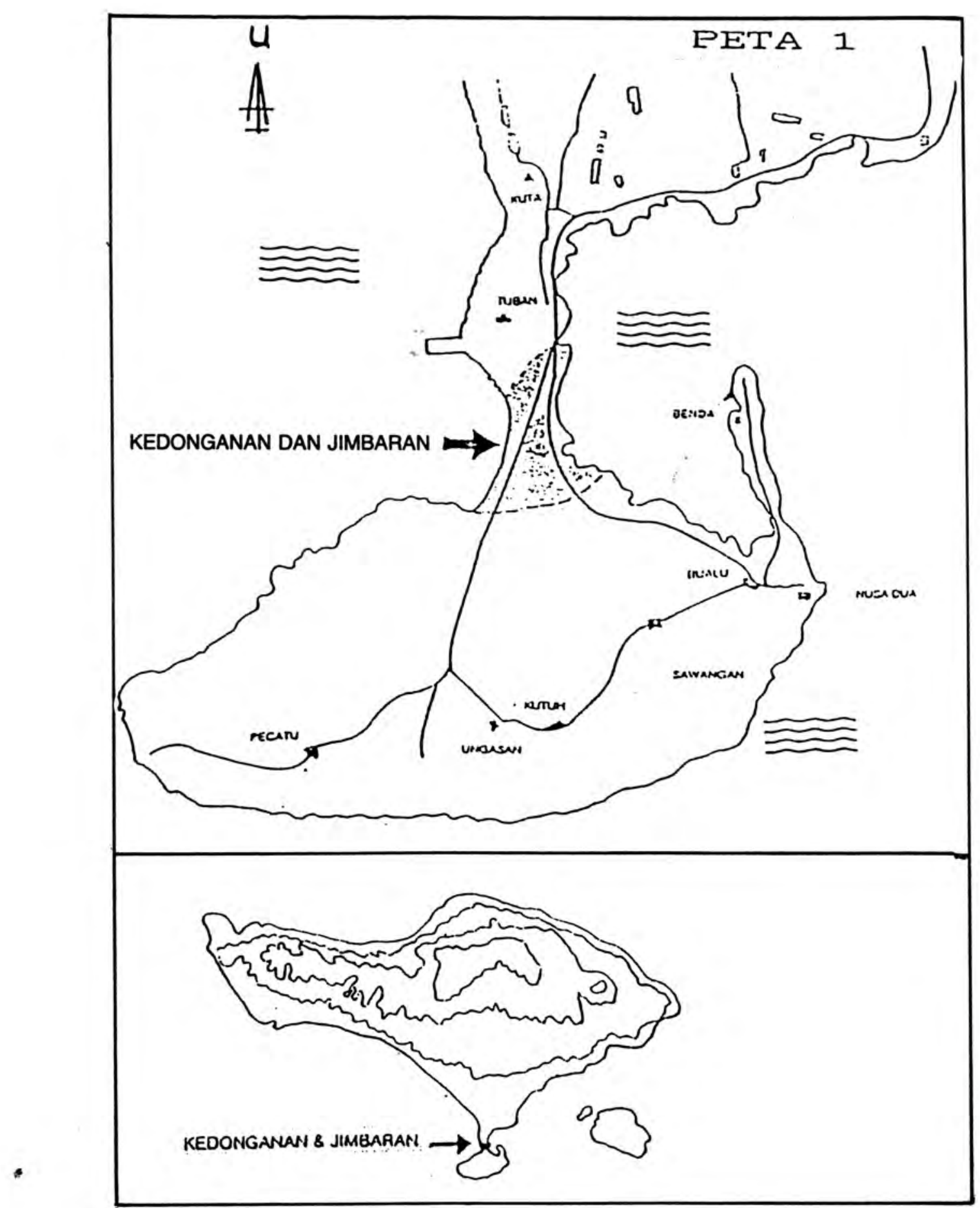

Lokasi Daerah Penelitian 

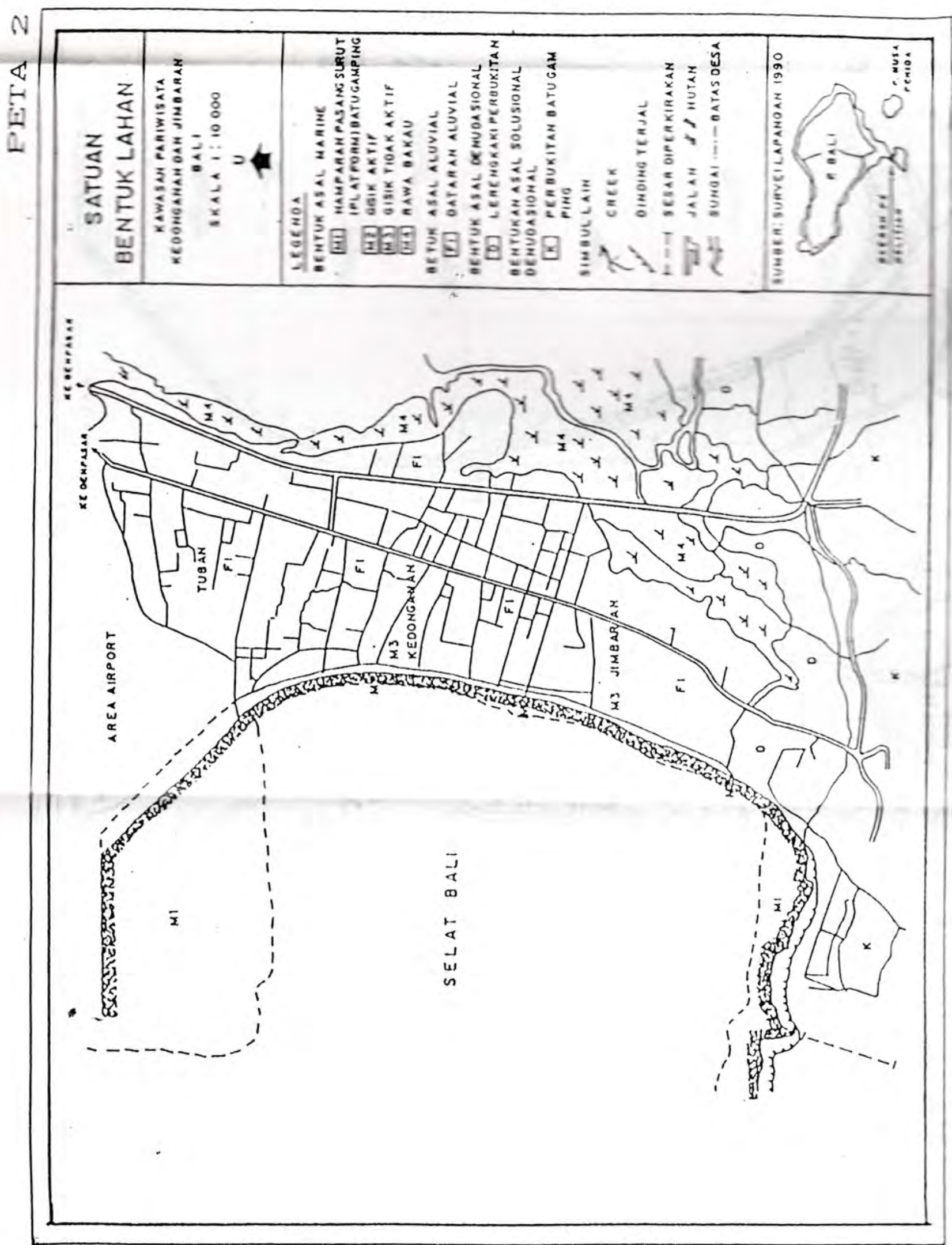
PETA 3

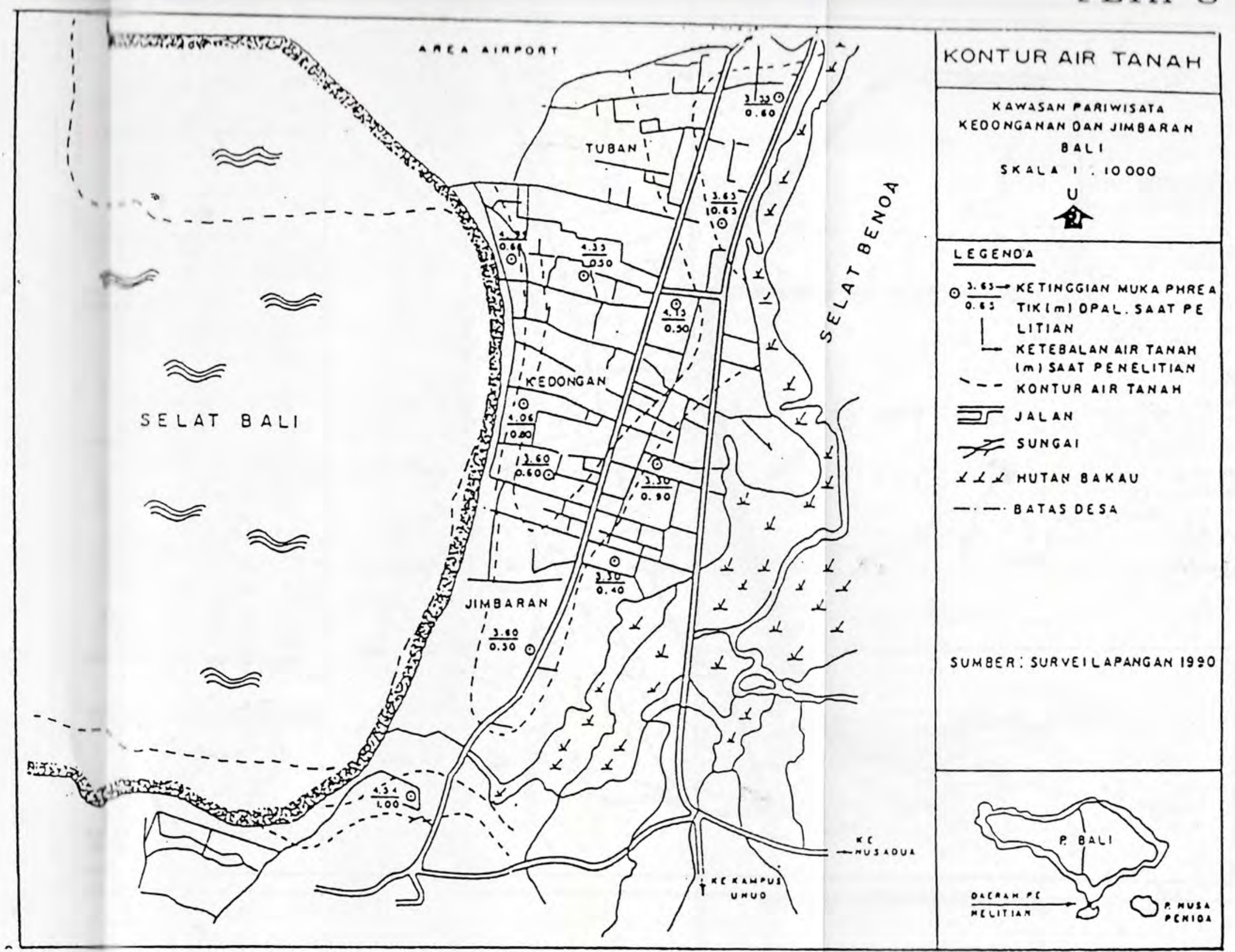


PETA 4

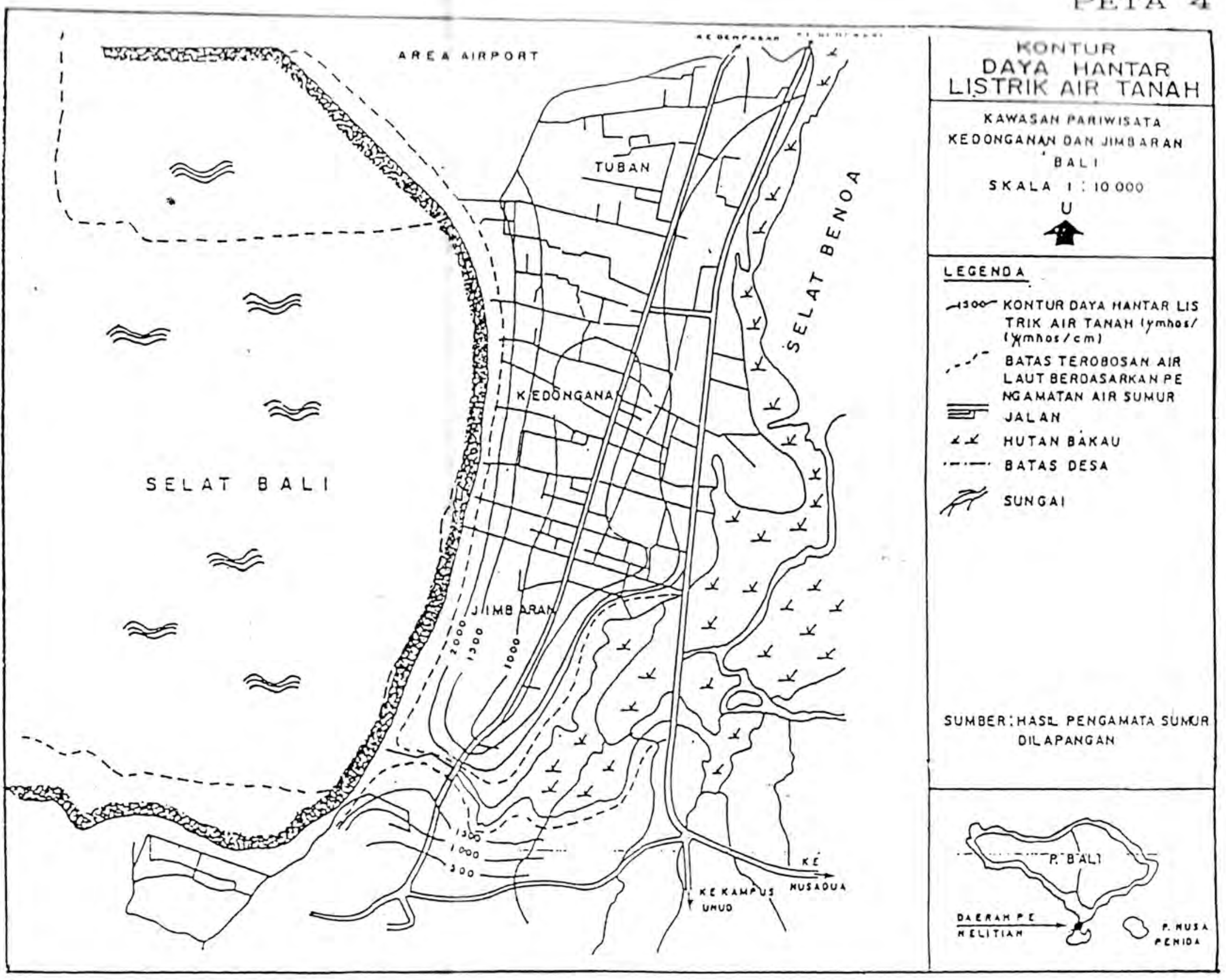




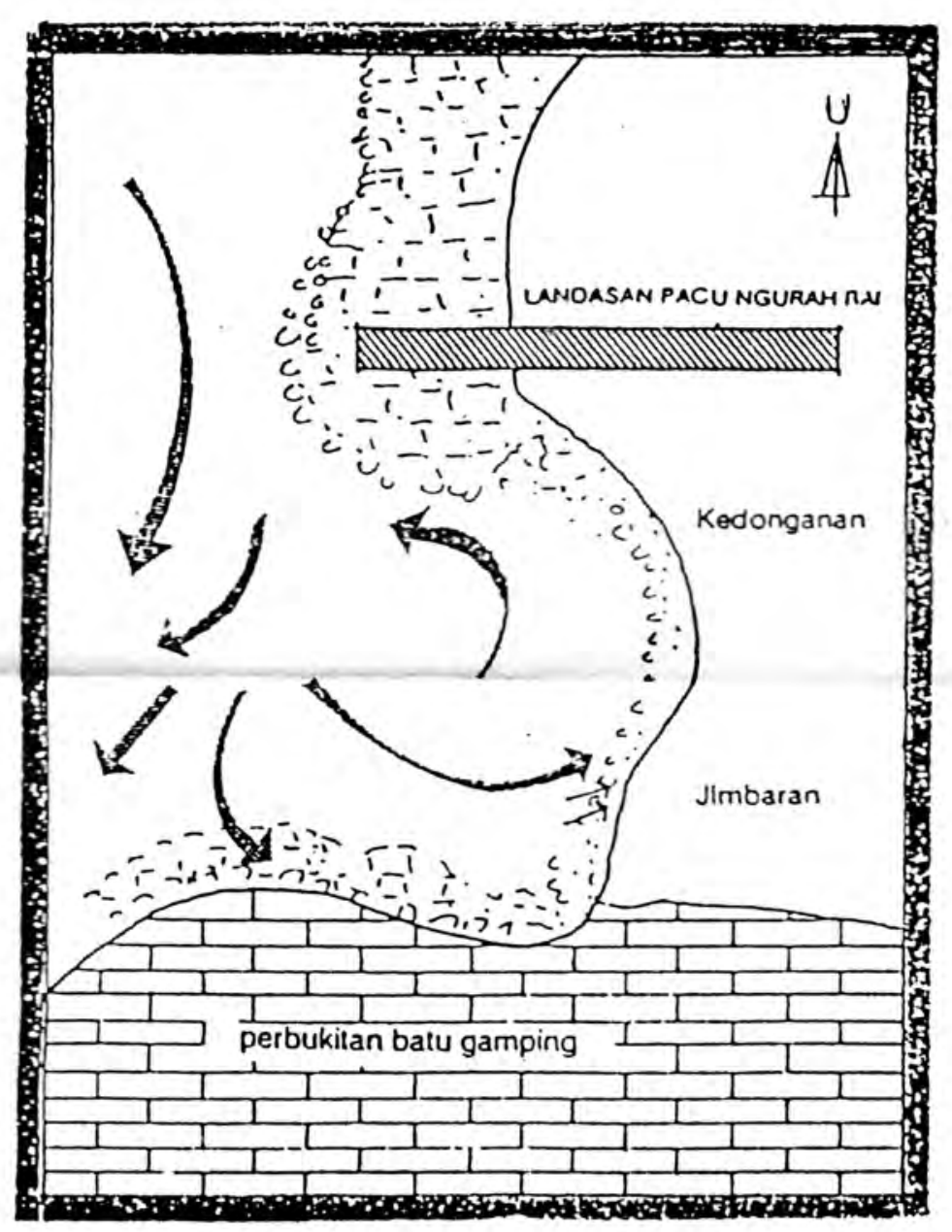

\section{KETERANGAN.}

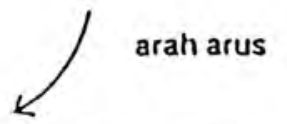

* $n^{n}$ gelombang pecah

द) abrasl

$\because \quad$ endapan pasir pantal

ב. pelataran gamplng koral (platlorm) 